\section{Intercropping Seedless Watermelon and Cotton}

Gilbert Miller ${ }^{1}$

Clemson University, Edisto Research and Education Center, 64 Research

Road, Blackville, SC 29817

\section{Jeremy Greene}

Clemson University, Plant and Environmental Sciences, Edisto Research and Education Center, 64 Research Road, Blackville, SC 29817

Additional index words. Citrullus lanatus, Gossypium hirsutum, land equivalent ratio, drip irrigation, land productivity

\begin{abstract}
Intercropping of seedless watermelon [Citrullus lanatus (Thumb.) Matsum. \& Nak.] and cotton [Gossypium hirsutum (L.)] in the eastern geographical area of South Carolina requires changes in normal crop-management programs but has the potential to improve grower profits compared with typical production of each crop separately. The alteration and timing of several normal crop-production practices for both crops can present challenges and must be well-defined for successful intercropping of watermelon and cotton in the region. Notable adjustments in production for watermelon are delayed planting date, reduced row spacing and bed width, and modification of herbicide applications. Significant changes in normal cotton production also include modification of herbicide applications, but additional considerations, such as temporal limits on sidedressed fertilizer and insecticide applications, are needed because of the raised beds and plasticulture used for watermelons and also because of labeling restrictions for pesticides across crops. Research was conducted to 1) identify modifications in standard cropmanagement procedures for watermelon and cotton intercropping; and 2) determine the feasibility and profitability of intercropping the crops. Although there was a slight numerical reduction in intercropped watermelon yield each year, there were no significant differences in total watermelon yield between intercropping and watermelon monoculture in any of the years. There were also no significant differences in watermelon fruit quality parameters (size, brix, hard seed, hollow heart) in any of the years. Intercropped cotton yield was significantly less than monoculture cotton yields in each of the three years. The net income from intercropping in each year was slightly less than the net income from watermelon monoculture.
\end{abstract}

Intercropping, the agricultural practice of cultivating two or more crops in the same space at the same time, can make more efficient use of arable land and increase perhectare profitability for growers (Kahn, 2010; Lithourgidis et al., 2011). Potential benefits of intercropping include increased water, nutrient, and light efficiency and reduced pest pressure (Machado, 2009; Risch, 1983; Sullivan, 2003). Intercropping also may provide insurance against crop failure (Horwith, 1985; Lithourgidis et al., 2011). If one crop of the mixture fails due to adverse environmental conditions, the other crop(s) might with-

\footnotetext{
Received for publication 26 July 2018. Accepted for publication 26 Sept. 2018.

This study was partially funded by the South Carolina Watermelon Association. This is technical contribution number 6685 of the Clemson University Experiment Station. This manuscript is based upon the work supported by the National Institute of Food and Agriculture/U.S. Department of Agriculture, under project number SC-1700441. We acknowledge Dan Robinson for technical assistance in planting, maintaining, and harvesting cotton plots.

${ }^{1}$ Corresponding author. E-mail: gmllr@clemson. edu.
}

stand the stresses and remain harvestable and profitable (Clawson, 1985). Intercropping has shown to be more productive when the component crops differ greatly in growth duration (Fukai and Trenbath, 1993).

Increasing land productivity and grower profits are likely the greatest benefits of intercropping. Success and efficiency of intercropping are commonly measured using the land-equivalent ratio (LER) (Francis and Decoteau, 1993), developed by Mead and Willey (1980). The LER is calculated as the yield of a crop in an intercrop system relative to the yield of that crop in a monocrop system (Kahn, 2010). The resulting number is a ratio and specifies the amount of land needed to grow intercropped vs. the amount of land needed to grow both crops individually and produce an equivalent yield. Intercropping favors the growth and yield of the species when the LER is greater than 1.0, but when LER is lower than 1.0, intercropping negatively effects the growth and yield of the plants grown in mixtures (Willey and Rao, 1980). However, according to Garnier et al. (1997), evaluating an intercropped vs. a monoculture system based on LER can be deceiving, and they proposed an alternative index. Garnier's index compares the yield of the intercropped or polyculture with the most-productive monoculture. Garnier proposes that for a polyculture to be better than a monoculture, it must yield better than the best monoculture. Trenbath (1974) had the same conclusion.

Although intercropping may improve land productivity and may improve grower profits, the combination of two or more crops may necessitate significant alterations in normal crop-production practices compared with monoculture of each crop (Willey et al., 1983). Many researchers have reported difficulties in managing combined crops, with negative consequences for one or both crops (Boehner et al., 1991; Lesoing and Francis, 1999; Santalla et al., 2001). Successful multiple cropping requires superior management skills (Bowen and Kratky, 1986). Because agronomic recommendations for many intercrop combinations do not exist (Machado, 2009), it is necessary to delineate management practices for an intercrop combination.

Intercropping watermelon and upland cotton is an effective approach to share land resources and production inputs as well as improve grower profitability and is being rapidly adopted by Georgia growers (Eure, 2014). A major impediment to the success of watermelon-cotton intercropping systems in Georgia is management of glyphosateresistant Palmer amaranth (Eure et al., 2012, 2013; Tankersley et al., 2011). Appropriate registrations of agrichemicals to be used in both crops can be an obstacle for intercropping as well (Kahn, 2010).

In South Carolina, $\approx 7000$ to 9000 acres of watermelon are planted annually (U.S. Department of Agriculture, National Agricultural Statistics Service, 2017). The greater part of this planted watermelon acreage employs a plasticulture production system incorporating drip irrigation. Of the roughly 158,296 reported acres of cotton planted in South Carolina during 2007, about $9 \%$ of the crop received irrigation that year (Payero and Khalilian, 2017), primarily from overhead irrigation systems. This is well below the reported $36 \%$ of upland cotton receiving irrigation in the United States in 2007 (U.S. Department of Agriculture, National Agricultural Statistics Service, 2012).

If intercropping of watermelon and cotton is to be successful in South Carolina, it is necessary to define the required modifications in standard practices. Thus, research was conducted to identify those alterations and to determine the feasibility and profitability of intercropping watermelon and cotton.

\section{Materials and Methods}

Research site and cultural practices. The study was conducted at the Clemson University Edisto Research and Education Center, near the town of Blackville, SC, in 2012, 2013, and 2014. The field was located at $33^{\circ} 21^{\prime} \mathrm{N}$ lat. and $81^{\circ} 19^{\prime} \mathrm{W}$ long. and $93 \mathrm{~m}$ above mean sea level. The soil in the 2012 and 2014 test field was classified as a Barnwell 
loamy sand. Soil maps from the Natural Resources Conservation Service (U.S. Department of Agriculture, Natural Resources Conservation Service, 2012) indicate that Barnwell loamy sand has a field capacity of $0.174\left(\mathrm{~cm}^{3} \cdot \mathrm{cm}^{3}\right)$ and a permanent wilting point of $0.061\left(\mathrm{~cm}^{3} \cdot \mathrm{cm}^{-3}\right)$ for the top $30 \mathrm{~cm}$ of soil with an available water capacity of $\approx 0.113\left(\mathrm{~cm}^{3} \cdot \mathrm{cm}^{-3}\right)$. Soil texture determinations showed sand prevailing to a depth of 20 $\mathrm{cm}$, loamy sand and sand at $30 \mathrm{~cm}$, sandy loam at $40 \mathrm{~cm}$, and sandy clay at $50 \mathrm{~cm}$. The soil in the 2013 test field was classified as Wagram sand with a field capacity of 0.107 $\left(\mathrm{cm}^{3} \cdot \mathrm{cm}^{-3}\right)$ and a permanent wilting point of $0.045\left(\mathrm{~cm}^{3} \cdot \mathrm{cm}^{-3}\right)$ for the top $30 \mathrm{~cm}$ of soil with an available water capacity of $\approx 0.062$ $\left(\mathrm{cm}^{3} \cdot \mathrm{cm}^{-3}\right)$. Soil texture analysis showed sand to a depth of $91 \mathrm{~cm}$.

The winter cover crop of Abruzzi rye (Secale cereal) and crimson clover (Trifolium incarnatum) was plowed down each year in mid-January. At this time, the field was tilled with bent-leg shanks (WorkSaver Inc., Litchfield, IL) to a depth of 45 to $50 \mathrm{~cm}$. Each year, black polyethylene mulch film (0.019 $\mathrm{mm}$ thick, $121.92 \mathrm{~cm}$ wide; Guardian AgroPlastics, Tampa, FL) and drip irrigation tubing (Aqua-Traxx; Toro Ag Irrigation, El Cajon, CA) were laid 1 week after preplant fertilizer application and several weeks before transplanting. The width of the raised bed covered by polyethylene mulch was $\approx 45.72 \mathrm{~cm}$ (18 inches). The polyethylene mulch and raised bed width used in this research was narrower than the standard mulch width of $137.16 \mathrm{~cm}$ and raised bed width of $76.2 \mathrm{~cm}$ that typically is used by commercial growers for watermelon production in South Carolina. The drip tape had an emitter spacing of $30 \mathrm{~cm}$ with a flow rate of $1.71 \mathrm{~L} / \mathrm{h}$ per emitter at $103.42 \mathrm{kPa}$. Row spacing was $\approx 193 \mathrm{~cm}$, with an in-row plant spacing of $121.92 \mathrm{~cm}$. Watermelons were sprayed with fungicides and insecticides as recommended (Keinath and Miller, 2012; Kemble, 2012), and cotton was managed following Clemson University Extension recommendations (Jones et al., 2011). Imidacloprid (AmTide Imidacloprid 2F, $1461 \mathrm{~mL} / \mathrm{ha}$; AmTide, LLC, Irvine, CA) was injected through the drip irrigation on 8 May 2012, 3 May 2013, and 7 May 2014.

All watermelon plants [AC 7167 (BASF Nunhems USA, Inc., Parma, ID), 2012; AC 7197 (BASF Nunhems USA), 2013, 2014] were grown from seed in a greenhouse at the Clemson University Edisto Research and Education Center. Transplants were grown in a soilless mix, Metro-Mix 360 (Sungro Horticulture Canada Ltd., Bellevue, WA). All seedlings were grown in 128 cell tapering trays (TLC Polyform, Inc., Morrow, GA). Watermelon plants were transplanted and watered in by hand on 24 Apr. each year. Mickylee (BASF Nunhems) plants were used as pollinizers at a one pollinizer plant to three seedless plants ratio. The cotton variety DP1050B2RF (Deltapine seed; Monsanto Company, St. Louis, MO), with thiamethoxam as an insecticide seed treatment, was planted each year at about $1 \mathrm{seed} / 10 \mathrm{~cm}$ on a row spacing of $96.5 \mathrm{~cm}$.

Treatments. During 2012 and 2013, treatments included watermelon alone, watermelon intercropped with cotton and side-dressed fertility, watermelon intercropped with cotton and no side-dressed fertility, cotton alone, cotton alone with side-dressed fertility, and cotton alone with no side-dressed fertility. During 2014, the aforementioned treatments were included, and two additional treatments were incorporated. Those were cotton intercropped with continued drip irrigation and fertigation and cotton intercropped with no continued drip irrigation and fertigation.

Experimental design and data analyses. The experiment used a split-plot experimental design with crop type (cotton alone, watermelon alone, intercropped) as the main plot factor and nutrient side dress application as the split-plot factor. The three crop types were randomly assigned to main plots and replicated four times. During 2014, two subplots testing drip irrigation and fertigation in each of the eight intercropped split plots were incorporated with eight replications.

Each watermelon alone and intercropped main plot consisted of six raised bed rows spaced $1.92 \mathrm{~m}$ center to center and covered with black polyethylene mulch. Each raised bed in each split plot contained ten watermelon plants spaced $1.22 \mathrm{~m}$ apart. Each cotton alone and intercropped split plot consisted of eight rows of cotton $96.5 \mathrm{~cm}$ apart at $\approx 9.8 \mathrm{seed} / \mathrm{m}$ (120 plants per $12.2 \mathrm{~m}$ row). Cotton rows were $\approx 22.9 \mathrm{~cm}$ to the side of each raised bed. All data were analyzed by analysis of variance with PROC MIXED and PROC GLIMMIX (SAS Institute, 2011), and means were separated with Fisher's least significance difference.

Herbicide application. Typical herbicide application for watermelon alone production was altered slightly due to the addition of the cotton crop. Typically, Strategy (Loveland Products, Inc., Loveland, CO), a combination of ethalfluralin and clomazone, is applied to the row middles of watermelons to control certain annual grasses and broadleaf weeds (Kemble, 2012). However, because clomazone can cause crop injury in cotton, a combination of ethalfluralin plus fomesafen (Reflex ${ }^{\circledR}$; Syngenta Crop Protection, LLC, Greensboro, NC) was applied. Immediately after cotton planting in each year (2 May 2012, 8 May 2013, and 8 May 2014), herbicides were applied with a shielded sprayer to the bare ground row middles alone. Each year, a tank mix of the following herbicides was applied to row middles of watermelon alone and watermelon intercropped with cotton immediately after cotton planting: ethalfluralin $(2.34 \mathrm{~L} / \mathrm{ha})$; fomesafen $(1.17 \mathrm{~L} /$ ha); and paraquat (Gramoxone Inteon ${ }^{\circledR}, 3.51$ L/ha; Syngenta Crop Protection, LLC, Greensboro, NC). The plots of cotton alone received herbicide applications of pyrithiobac sodium $\left(\right.$ Staple $^{\circledR}, 204.6 \mathrm{~mL} / \mathrm{ha}$; E.I. du Pont de Nemours and Company, Wilmington, DE) and Glyphosate (Roundup Weath-
$\operatorname{erMax}^{\circledR}, 1.6 \mathrm{~L} / \mathrm{ha}$; Monsanto Company) each year. Herbicide applications to the plots of cotton alone were made on 16 May 2012, 4 June 2013, and 16 June 2014.

Irrigation management. As a general rule, watermelon crops require 30.7 to $92 \mathrm{~mm} /$ acre of water per week (Kemble, 2012). Less is required during early season growth, but more is needed during fruit swell. Research has shown that under a plasticulture system with a $76.2 \mathrm{~cm}$ raised bed width, as much as $85 \%$ of the root length density can be found in the top $30 \mathrm{~cm}$ of soil depth (Miller et al., 2013). To compensate for the reduced rooting area $(40 \%$ reduction in standard raised bed width) and the addition of cotton plants $\approx 20.9 \mathrm{~cm}$ to the side of each raised bed, it was decided to increase the weekly application of water to $32 \mathrm{~mm}$. Drip irrigation was initiated $2 \mathrm{~d}$ before transplanting, and all plots received the same programmed daily irrigation. The daily early season drip irrigation program specified three 45-minute irrigation cycles with each cycle delivering $\approx 1.524 \mathrm{~mm}$ water. An additional 45 -minute irrigation cycle was programed beginning at watermelon fruit swell, which delivered weekly $40.64 \mathrm{~mm}$ of water. After the final watermelon harvest, fertigation was discontinued and drip irrigation programs were reduced to two 45-minute cycles per day and continued on all intercropped cotton/ watermelon plots until 16 Aug. in 2012 and 2013 (Table 1). During 2014, following the final watermelon harvest (30 July), half of the intercropped cotton/watermelon plots continued to receive drip irrigation with two 45minute cycles per day, and the other half received no drip irrigation (Table 2).

Nutrient management. During early March, preplant fertilizer was applied broadcast: $38 \mathrm{~kg} /$ ha of nitrogen $(\mathrm{N})$, phosphorous, and potassium (K) in $2012 ; 67 \mathrm{~kg} / \mathrm{ha} \mathrm{N}$ and $\mathrm{K}$ in 2013; and $67 \mathrm{~kg} / \mathrm{ha}$ of $\mathrm{N}$ and $\mathrm{K}$ in 2014. During each year, $67 \mathrm{~kg} / \mathrm{ha}$ of $\mathrm{N}$ was applied as a side dress in the designated intercropped cotton/watermelon plots and the cotton alone plots using a Coulter nitrogen applicator (Reddick Equipment Company, Williamston,

Table 1. Season length and season water application

\begin{tabular}{lrrr}
\hline & \multicolumn{3}{c}{ Yr } \\
\cline { 2 - 4 } Factors & 2012 & 2013 & \multicolumn{1}{c}{2014} \\
\hline Season length $\left(\mathrm{d}^{\mathrm{z}}\right)$ & 88 & 92 & 98 \\
Irrigation $(\mathrm{min})$ & 13,275 & 13,995 & 15,075 \\
Water applied $\left(\mathrm{mm}^{\mathrm{y}}\right)$ & 432 & 456 & 491 \\
\hline
\end{tabular}

${ }^{\mathrm{z}}$ Season began at transplanting and ended at final harvest.

${ }^{\mathrm{y}}$ Total irrigation per 2,214 linear row meters.

Table 2. 2014 cotton intercropped after 30 July watermelon harvest.

\begin{tabular}{lr}
\hline Season length $\left(\mathrm{d}^{\mathrm{z}}\right)$ & 77 \\
Irrigation $(\mathrm{min})$ & 13,860 \\
Water applied $\left(\mathrm{mm}^{\mathrm{y}}\right)$ & 451 \\
Fertigation $(\mathrm{kg} \mathrm{N}$ and $\mathrm{K} / \mathrm{ha})$ & 77 \\
\hline
\end{tabular}

${ }^{\mathrm{z}}$ Season began at 30 July watermelon termination to 14 Oct. cotton harvest.

${ }^{\mathrm{y}}$ Irrigation per 2,214 linear row meters. 
NC). No side-dress application was applied to plots of watermelon alone. Side-dress applications of $\mathrm{N}$ were made on 13 May 2012, 14 June 2013, and 26 May 2014. Fertigation began the day of transplanting. The amount of nutrients delivered through fertigation was small initially, gradually increased through the growing season, and reached maximum during fruit swell (Table 3). Fertigation ended with the last watermelon harvest on 20 and 24 July, in 2012 and 2013, respectively. In 2014, after the last watermelon harvest, half the intercropped cotton/watermelon plots continued to receive fertigation at $1.12 \mathrm{~kg} / \mathrm{ha}$ of $\mathrm{N}$ and $\mathrm{K}$ per day and the other half received no fertigation (Table 2).

Watermelon yield and quality. Ripe watermelons were harvested based on commonly used field indicators of maturity, including brown tendril located next to the fruit, yellowing on underside of fruit, and a general loss of rind gloss. All fruit were weighed, and the total weight (kilogram) and number (count) of fruit per plot were recorded for all harvests. Four harvests were conducted in 2012 and 2014 and two harvests in 2013. During the first two harvests of each year, a subsample of five fruit were randomly selected for quality measurements, which included soluble solids ( ${ }^{\circ}$ Brix), number of black seed (count), and hollow heart incidence (length $\times$ width, $\mathrm{cm}^{2}$ ).

Cotton yield. After defoliation, the center four rows of each cotton plot were harvested with a two-row mechanical picker. Watermelons were ended with glyphosate on 22 , 24 , and 30 July for years 2012, 2013, and 2014 , respectively. Cotton was harvested on 20 and 5 Dec. and 20 October for 2012, 2013, and 2014 , respectively.

\section{Results}

There were some significant differences between years in each of the environmental categories (Table 4). The season length, transplant to final harvest, was greatest in 2014, evapotranspiration was greater in 2012 , and 2013 had the highest precipitation. The precipitation in $2013,576 \mathrm{~mm}$, was significantly greater than average precipitation, $356 \mathrm{~mm}$ (The Weather Company, 2018).

Watermelon yield. Although the 3-year trend for watermelon yields alone was slightly greater than watermelon yields intercropped with cotton, in each of the 3 years there were no significant differences in watermelon yields between watermelon alone and watermelon intercropped with cotton (Table 5). Watermelon yields in 2012 and 2014 were above the South Carolina state average, but yields during 2013 were significantly below the state average. The market price for South Carolina watermelons and crop value at each harvest date for each year are shown in Table 6 (U.S. Department of Agriculture Market Service, 2014).

The watermelons intercropped with cotton that received $67 \mathrm{~kg} / \mathrm{ha}$ of $\mathrm{N}$ as a side dress did not show any significant yield increase

Table 3. Watermelon fertigation rates and total amounts by year.

\begin{tabular}{|c|c|c|c|c|c|c|}
\hline \multirow{2}{*}{$\begin{array}{l}\text { Rate }(\mathrm{kg} \mathrm{N} \\
\text { and } \mathrm{K} / \mathrm{ha})\end{array}$} & \multicolumn{2}{|c|}{2012} & \multicolumn{2}{|c|}{2013} & \multicolumn{2}{|c|}{2014} \\
\hline & Days & Total kg & Days & Total kg & Days & Total kg \\
\hline 0.56 & 19 & 10.64 & 27 & 15.12 & 0 & 0 \\
\hline 1.12 & 10 & 11.2 & 7 & 7.84 & 8 & 8.96 \\
\hline 1.68 & 7 & 11.76 & 13 & 21.84 & 10 & 16.8 \\
\hline 2.24 & 20 & 44.8 & 10 & 22.4 & 58 & 129.92 \\
\hline 2.8 & 30 & 84 & 33 & 92.4 & 0 & 0 \\
\hline Total & 86 & 162.4 & 90 & 159.6 & 76 & 155.68 \\
\hline
\end{tabular}

Table 4. Environmental conditions for watermelons each year.

\begin{tabular}{lrrr}
\hline & \multicolumn{1}{c}{ Yr } \\
\cline { 2 - 4 } Factor & 2012 & 2013 & 2014 \\
\hline Season length $\left(\mathrm{d}^{\mathrm{z}}\right)$ & 88 & 92 & 98 \\
Rainfall total $(\mathrm{mm})$ & 380 & 576 & 282 \\
ETo total $(\mathrm{mm})$ & 423 & 299 & 277 \\
\hline
\end{tabular}

${ }^{\mathrm{z}}$ Season began at transplanting and ended at final harvest.

ETo $=$ evapotranspiration.

Table 5. Fruit and cotton yield from each of the treatments in 2012, 2013, and 2014. ${ }^{\mathrm{z}}$

\begin{tabular}{|c|c|c|}
\hline Treatment & Yield (kg/ha) & $P$ value \\
\hline \multicolumn{3}{|l|}{2012} \\
\hline 1. Watermelon interplanted & $107,994 \mathrm{a}$ & 0.3343 \\
\hline Watermelon alone & $115,169 \mathrm{a}$ & \\
\hline 2. Watermelon interplanted with side-dress & $106,097 \mathrm{a}$ & 0.4426 \\
\hline Watermelon interplanted with no side-dress & $111,906 \mathrm{a}$ & \\
\hline 3. Cotton interplanted & $726 a$ & 0.0147 \\
\hline Cotton alone & $1,143 \mathrm{~b}$ & \\
\hline 4. Cotton interplanted with side-dress & $715 \mathrm{a}$ & 0.8167 \\
\hline Cotton interplanted with no side-dress & $736 \mathrm{a}$ & \\
\hline 5. Cotton alone with side-dress & $1,145 \mathrm{a}$ & 0.983 \\
\hline Cotton alone with no side-dress & $1,141 \mathrm{a}$ & \\
\hline \multicolumn{3}{|l|}{ (2) } \\
\hline 1. Watermelon interplanted & $32,585 \mathrm{a}$ & 0.8318 \\
\hline Watermelon alone & $33,170 \mathrm{a}$ & \\
\hline 2. Watermelon interplanted with side-dress & 30,402 a & 0.9998 \\
\hline Watermelon interplanted with no side-dress & 33,704 a & \\
\hline 3. Cotton interplanted & $174 \mathrm{~b}$ & 0.0147 \\
\hline Cotton alone & $778 \mathrm{a}$ & \\
\hline 4. Cotton interplanted with side-dress & $214 \mathrm{a}$ & 0.0627 \\
\hline Cotton interplanted with no side-dress & $134 \mathrm{a}$ & \\
\hline 5. Cotton alone with side-dress & 809 a & 0.7337 \\
\hline Cotton alone with no side-dress & $748 \mathrm{a}$ & \\
\hline \multicolumn{3}{|l|}{ - } \\
\hline 1. Watermelon interplanted & $120,249 \mathrm{a}$ & 0.4967 \\
\hline Watermelon alone & $127,801 \mathrm{a}$ & \\
\hline 2. Watermelon interplanted with side-dress & $124,838 \mathrm{a}$ & 0.9175 \\
\hline Watermelon interplanted with no side-dress & $123,754 \mathrm{a}$ & \\
\hline 3. Cotton interplanted & $1,353 \mathrm{~b}$ & 0.0019 \\
\hline Cotton alone & $2,097 \mathrm{a}$ & \\
\hline 4. Cotton interplanted with side-dress & $1,359 \mathrm{a}$ & 0.9237 \\
\hline Cotton interplanted with no side-dress & $1,347 \mathrm{a}$ & \\
\hline 5. Cotton alone with side-dress & $2,156 \mathrm{a}$ & 0.2456 \\
\hline Cotton alone with no side-dress & $2,035 \mathrm{a}$ & \\
\hline 6. Cotton interplanted with drip irrigation and fertigation. & $1,454 \mathrm{a}$ & 0.0565 \\
\hline Cotton interplanted no drip irrigation or fertigation. & $1,202 \mathrm{a}$ & \\
\hline
\end{tabular}

${ }^{\mathrm{z}}$ Within numbered comparisons, different letters indicate a significant difference $(P<0.05)$.

compared with watermelon intercropped with cotton and no $\mathrm{N}$ side dress in any of the test years (Table 5). There were no significant differences in the fruit quality measurements of soluble solids ( ${ }^{\circ}$ Brix $)$, number of black seed (count), or hollow heart incidence (length $\times$ width, $\mathrm{cm}^{2}$ ) in any year (data not shown).

Cotton yield. When intercropped with watermelon, cotton yields were significantly less than those with cotton produced alone each year (Table 6). Yield reductions in cotton intercropped with watermelons in 2012 and 2014, when compared with the cotton alone treatment, were 36.5 and $35.5 \%$, respectively. The yield reduction in cotton intercropped with watermelon in 2013 was $77.7 \%$ less than the yield for the cotton alone treatment. Supplemental N applied as a side-dress treatment did not improve cotton yields during any year.

\section{Discussion}

Compared with yields from monocultured watermelons, yields from watermelon intercropped with cotton were not significantly reduced in any year. In 2012 and 2014, yields 
Table 6. Crop yield, market value, variable costs, net value, and LER for cotton and watermelon grown in monoculture and in intercropping systems.

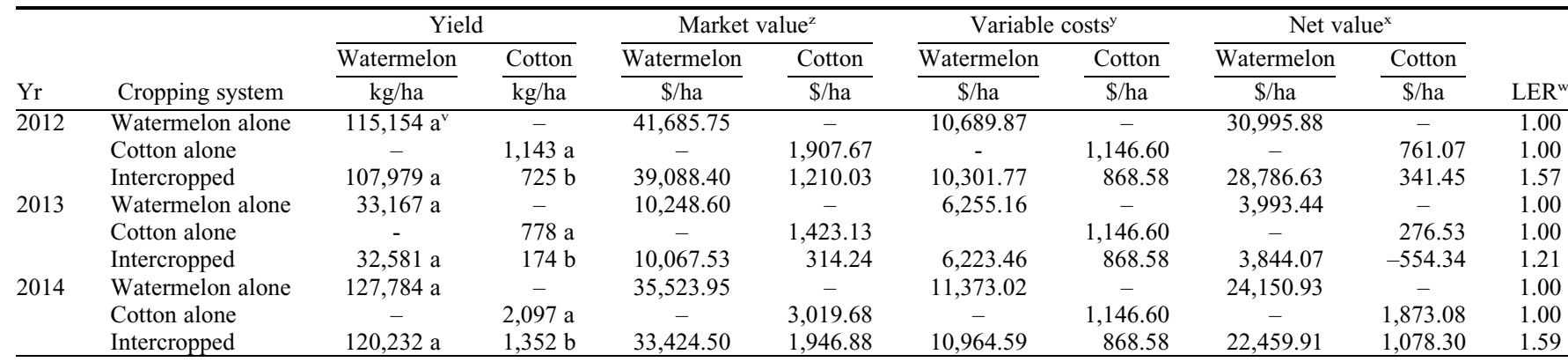

${ }^{\mathrm{z}}$ Market value of watermelons used was the mean value of all market prices at time of harvest for each year. Market prices ( $\left.\$ / \mathrm{kg}\right)$, respectively, for years 2012 , 2013 , and 2014 were $\$ 0.362, \$ 0.309$, and $\$ 0.278$. Market prices of cotton were market prices $(\$ / \mathrm{kg})$ at time of sale each year and, respectively, for years 2012 , 2013 , and 2014 were $\$ 1.669, \$ 1.806$, and $\$ 1.440$.

${ }^{{ }}$Base value of variable costs for watermelons used was $\$ 6,537.46$ ha. Yearly increase or decrease in harvest costs was added or subtracted. Variable cost of monoculture cotton was $\$ 1,146.60$ ha, whereas variable costs were reduced to $\$ 868.58$ ha in intercropping because of shared inputs.

${ }^{\mathrm{x}}$ Net value was calculated by subtracting variable costs from market value.

${ }^{\mathrm{w}}$ LER compares the yields from growing two or more crops together with yields from growing the same crops in monocultures. An LER $>1.0$ usually shows that intercropping is advantageous and $<1.0$ show a disadvantage.

${ }^{v}$ Within yield columns, letters indicate a significant difference $(P<0.05)$, Fisher's least significant difference.

$\mathrm{LER}=$ land-equivalent ratio.

from intercropped and monocultured watermelons were above the state average in South Carolina, but yields during 2013 were significantly below the state average. The excessive seasonal rainfall in $2013,62 \%$ greater than average, combined with the coarse, sandy soil, most likely resulted in excessive leaching of nutrients. Furthermore, the test field also had a significant population of yellow nutsedge (Cyperus esculentus) that likely also contributed to lower watermelon yields in 2013. No in-row herbicide treatment was applied to control yellow nutsedge.

Although yields were reduced each year in cotton intercropped with watermelon compared with monocultured cotton, the net value per acre from intercropping systems was similar but slightly less than the watermelon monoculture systems. Several factors are important when evaluating the success and efficiency of interplanting of watermelon and cotton, including the LER, proposed by Mead and Willey (1980), commonly used to evaluate the effectiveness of intercropping systems. Because LER values were greater than 1.0 each year, the ratio indicated a favorable intercropping system (Table 6). In opposition, the evaluating index proposed by Garnier et al. (1997) and supported by Trenbath (1974) indicated that the intercropping system was not better because it did not yield better than the best monoculture system.

Unlike the results from intercropping of watermelon and cotton observed in Georgia (Eure, 2014), our watermelon and cotton intercropping results did not indicate an increase in unit of land profitability. Although the Georgia results showed a significant increase in yield with intercropped watermelon vs. monoculture, our results showed no change in watermelon yields when intercropped with cotton. Also, unlike the Georgia research, glyphosate-resistant Palmer amaranth (Amaranthus palmeri) was not a significant problem in any of the test years in our fields. This was probably due to no historical production of cotton in the test area used.
As Willey et al. (1983) indicated, intercropping systems may necessitate significant alterations in normal crop-production practices compared with monoculture of each crop. There were significant alterations, particularly with watermelon production practices. Foremost was the necessity of a global positioning system guidance system when laying plastic mulch and drip tape and subsequent cotton planting. With cotton rows at $96.5 \mathrm{~cm}$ spacing and $\approx 22.9 \mathrm{~cm}$ on each side of the plastic mulch bed, uniform and accurate spacing of plastic mulch on the bed was a necessity.

To allow for the $96.5-\mathrm{cm}$ cotton row spacing, the normal plastic mulch bed width in South Carolina of $11.8 \mathrm{~cm}$ was reduced to $7 \mathrm{~cm}$. Although on-farm row spacing for monoculture watermelon production varies from 1.83 to $3.66 \mathrm{~m}$, the most predominant row spacing is $2.44 \mathrm{~m}$. To accommodate the cotton rows at $96.5 \mathrm{~cm}$, the intercropped watermelon row spacing was altered to $1.92 \mathrm{~m}$. Consequently, the in-row spacing of watermelon plants was increased to $1.22 \mathrm{~m}$ to allow for the recommended $2.23 \mathrm{~m}^{2}$ per plant (Kemble, 2012).

Another significant alteration in normal monoculture watermelon production practices to accommodate the intercropping system is a later-than-normal planting date for watermelon. Planting dates for cotton in the southern portion of South Carolina depend on environmental conditions, particularly soil temperatures, but early May planting is common (Jones et al., 2011). Herbicide application must be made immediately after cotton planting and before germination of cotton seed. Early April is the normal planting time for watermelon transplants in the southern area of South Carolina. To ensure that the watermelon vines did not extend beyond the narrow 7- $\mathrm{cm}$ bed width when herbicide applications were made, the watermelon planting date was delayed until 24 Apr. each year. The delayed planting date for intercropped watermelon resulted in later-than-normal watermelon harvests each year. Historically, watermelon price per pound has slightly declined after the peak July fourth market window (U.S. Department of Agriculture Market Service, 2014). This is a concern, but late-season prices for watermelon each test year were adequate (Table 6).

Although the intercropping of watermelons and cotton could be considered to be a more efficient use of arable land, an increase in profitability per hectare was not realized in this research. The alterations in normal production practices for both crops required for intercropping systems, additional management requirements, additional risks, and slightly less economic returns with intercropping indicates that intercropping of watermelon and cotton might not be appropriate for South Carolina farmers.

\section{Literature Cited}

Boehner, P., G. Lesoing, and C.A. Francis. 1991. Strip cropping of grain sorghum/soybeans under dryland and irrigation in eastern Nebraska, p. 39. In: Agronomy abstracts. Agronomy Society of America, Madison, WI

Bowen, J.F. and B.A. Kratky. 1986. Successful multiple cropping requires superior management skills. Agribusiness Worldwide November/December:22-30.

Clawson, D.L. 1985. Harvest security and intraspecific diversity in traditional tropical agriculture. Econ. Bot. 39:56-67.

Eure, P. 2014. Cotton and peanut tolerance to pyroxasulfone and weed management when intercropping cucurbits and cotton in Georgia. (Doctoral dissertation) $<\mathrm{http}$ //purl.galileo.usg. edu/uga_etd/eure_peter_m_201405_phd.>.

Eure, P.M., A.S. Culpepper, and R.M. Merchant. 2013. Weed management and crop response when intercropping cantaloupe and cotton, $\mathrm{p}$. 115. In: Southern Weed Science of Society abstracts. Southern Weed Science Society, Houston, TX.

Eure, P.M., A.S. Culpepper, T.B. Tankersley, and R.M. Merchant. 2012. Weed management and crop injury when intercropping melons and cotton, p. 1533-1534. In: Proceedings of the Beltwide Cotton Conference. National Cotton Council, Orlando, FL. 
Francis, R. and D.R. Decoteau. 1993. Developing an effective southernpea and sweet corn intercrop system. HortTechnology 3:178-184.

Fukai, S. and B.R. Trenbath. 1993. Processes determining intercrop productivity and yields of component crops. Field Crops Res. 14:263-290.

Garnier, E., M.-L. Navas, M.P. Austin, J.M. Lilley, and R.M. Gifford. 1997. A problem for biodiversityproductivity studies: How to compare the productivity of multispecific plant mixtures to that of monocultures? Acta Oecol. 18(6):657-670.

Horwith, B. 1985. A role for intercropping in modern agriculture. Biological Sciences 35: 286-291.

Jones, M.A., J.K. Greene, M. Marshall, and J.D. Mueller. 2011. South Carolina cotton growers' guide, pub. EC 589. Clemson University, Clemson, SC.

Kahn, B.A. 2010. Intercropping for field production of peppers. HortTechnology 20:530-532.

Keinath, A.P. and G.A. Miller. 2012. Watermelon spray guide for 2012. Clemson Cooperative Extension Information Leaflet 86. 6 May 2018. $<$ https://www.clemson.edu/extension/publications/ files/horticulture/hor01-watermelon-fungicideguide.pdf $>$.

Kemble, J. (ed.). 2012. Vegetable crop handbook for the Southeastern US. Vance Publishing Corp., Lincolnshire, IL.

Lesoing, G.W. and C.A. Francis. 1999. Strip intercropping effects on yield and yield components of corn, grain sorghum, and soybean. Agron. J. 91:807-813.

Lithourgidis, A.S., C.A. Dordas, C.A. Damalas, and D.N. Vlachostergios. 2011. Annual intercrops: An alternative pathway for sustainable agriculture. Austral. J. Crop Sci. 5(4):396-410.
Machado, S. 2009. Does intercropping have a role in modern agriculture? J. Soil Water Conserv. 84:55-57.

Mead, R. and R.W. Willey. 1980. The concept of a "Land Equivalent Ratio" and advantages in yields from intercropping. Expt. Agr. 16:217228.

Miller, G.A., A. Khalilian, J.W. Adelberg, H.J. Farahani, R.L. Hassell, and C.E. Wells. 2013. Grafted watermelon root length density and distribution under different soil moisture treatments. HortScience 48:1021-1026.

Payero, J. and A. Khalilian. 2017. Comparison of irrigated and dryland crop production in SC. Clemson Cooperative Extension, Fact Sheet AC07. Oct. 2017. <https://www.clemson.edu/ extension/publications/files/agronomic-crops/ AC07Comparison-of-irrigated-and-dryland-cropproduction-in-sc.pdf $>$.

Risch, S.J. 1983. Intercropping as cultural pest control: Prospects and limitations. Environ. Mgt. 7:9-14.

Santalla, M., A.P. Rodino, P.A. Casquero, and A.M. de Ron. 2001. Interactions of bush bean intercropped with field and sweet maize. Eur. J. Agron. 15:185-196.

SAS Institute. 2011. User's manual, version 9.3. SAS Institute, Cary, NC.

Sullivan, P. 2003. Intercropping principles and production practices. Appropriate technology transfer for rural areas. 31 Dec. 2017. <http:// www.attra.ncat.org $>$.

Tankersley, T.B., J. Chafin, A. Smith, P. Roberts, G. Collins, D. Langston, J. Dillard, and W. Dillard. 2011. Evaluation of cantaloupe and cotton intercropping to determine economic feasibility and growth compatibility, p. 146-147.
In: Proceedings Beltwide Conference. National Cotton Council, Memphis, TN.

Trenbath, B.R. 1974. Biomass productivity of mixtures. Adv. Agron. 26:177-210.

The Weather Company. 2018. Barnwell, SC (29812) monthly weather. 20 Mar. 2018. <https:// weather.com/weather/monthly/1/Barnwell+SC+ 29812:4:US>.

U.S. Department of Agriculture Market Service. 2014. Market research and analysis. 20 Mar. 2018. <https://www.ams.usda.gov/services/ market-research $>$.

U.S. Department of Agriculture, National Agricultural Statistics Service. 2012. Census of Agriculture. 2 Mar. 2018. <https://quickstats.nass. usda.gov/results/D05980CD-97E3-3176-9EBCC6F7277F65DE $>$.

U.S. Department of Agriculture, National Agricultural Statistics Service. 2017. State Agriculture Overview for South Carolina. 2017. 6 May 2018. <https://www.nass.usda.gov./Quick_ Stats/Ag_Overview/stateOverview.php?state= SOUTH $\% 20$ CAROLINA>.

U.S. Department of Agriculture, Natural Resources Conservation Service. 2012. Web Soil Survey. 26 Sept. 2018. <https://websoilsurvey.sc.egov. usda.gov/App/HomePage.htm>.

Willey, R.W., M. Natarajan, M.S. Reddy, M.R. Rao, P.T.C. Nambiar, J. Kannaiyan, and V.S. Bhatnagar. 1983. Intercropping studies with annual crops, p. 83-100. In: J. Nugent and M. O'Connor (eds.). Ciba Foundation Symposium 97-Better Crops for Food. John Wiley \& Sons, Ltd., Chichester, UK

Willey, R.W. and M.R. Rao. 1980. A competitive ratio for quantifying competition between intercrops. Expt. Agr. 16:117-125. 